\title{
Impact of Frontline Demonstration on the Yield and Economics of Chickpea (Cicer arietinum L.) production in Rajkot District of Gujarat
}

\author{
S.V. Undhad*, V.S. Prajapati, P.S. Sharma and N.B. Jadav
}

Krishi Vigyan Kendra, Junagadh Agricultural University, Pipalia (Rajkot), Gujarat, India

*Corresponding author

\section{A B S T R A C T}

\section{Keywords}

Chickpea, Frontline demonstration,

Yield, Economics,

Technology gap,

Extension gap,

Technology index

Article Info

Accepted:

04 July 2019

Available Online:

10 August 2019
The present work was carried out during Rabi season in ten farmer's field of Rajkot district during 2015-16 to 2017-18 in 12 hectare by active participation of 30 numbers of farmers. This programme is with the objective to demonstrate the improved variety of chickpea GG- 5 for production potential. These focused on increased the chickpea productivity, replacement of old variety with promising high yielding improved variety and get feedback from farmers on the performance of chickpea variety. The demonstrated variety GG -5 performed better in all yeas compare to farmers practices. In demonstrated plot the average yield of three years was recorded $2590 \mathrm{~kg} / \mathrm{ha}$ as compared to local variety $2193 \mathrm{~kg} / \mathrm{ha}$. The average percent increase in yield of demonstrated plot was recorded $13.66 \%$ during the three year of programmes. Technology gap, Extension gap and technology index values were $410 \mathrm{~kg} / \mathrm{ha}, 396.66 \mathrm{~kg} / \mathrm{ha}$ and $13.66 \%$, respectively. The research practices gave higher average gross return (Rs. 140931 /ha), net return (Rs. 83927 /ha) with higher $\mathrm{B}: \mathrm{C}$ ratio $(1: 2.46)$ as compared to framer's practices. By conduction of front line demonstrations on farmer's field there was significant increase in knowledge level of the farmer's and majority of farmer's showed high level of satisfaction about improved variety GG - 5 of chickpea.

\section{Introduction}

Chickpea (Cicer arietinum L.) is the largest produced food legume in south Asia and the $3^{\text {rd }}$ largest produced food legume globally after common bean and field pea. Chickpea is one of important pulse crop in India, accounting 75 percent of world production. Chickpea in India is grown on $7.58 \mathrm{~m}$ ha with 5.75 million tonne production and an average productivity of $793 \mathrm{~kg} / \mathrm{ha}$. Gujarat Shares $2.92,3.65$ and 0.25 per cent area, production and productivity, respectively of the nation under chickpea. However, at present the average productivity in the state is high (1008 $\mathrm{kg} / \mathrm{ha}$ ) compared to national level (Anonymous, 2009). In the Rajkot district of Gujarat farmer generally retain their own seeds, which are of poor quality besides being admixture of various varieties. Timely non- 
availability of improved varieties due to nonsystematic seed multiplication of chickpea is one of the factors responsible for low chickpea production. There is a too much scope to increase the production and productivity in state by transfer of technology of chickpea production. The Indian Council of Agricultural Research, has implemented a new fully funded programme in mid-eighties i.e. Front Line Demonstrations for transfer of technology to farmers. The main objective of front line demonstrations is to demonstrate newly released crop production technologies and its management practices in the farmer's field under farming situations and at different agro climatic regions (Meena, 2011 and Narasimha Rao et al., 2007). The field demonstrations conducted under the close supervision of scientists of the National Agriculture Research System is called frontline demonstrations because the technologies are demonstrated and critically examined by the scientists themselves before being fed into the main extension system of the State Department of agriculture. While demonstrating the technologies in the farmer's field, the scientists are required to study the factors contributing to higher crop production, production constraints and thereby, generate production data and feedback information.Under this unique programme, Krishi Vigyan Kendra, JAU, Pipalia, has conducted the front line demonstrations (FLD's) on chickpea in Thirty demonstration from 2015-16 to 2017-18 in jurisdiction of Krishi Vigyan Kendra. The present study has been undertaken to evaluate the difference between demonstrated technologies followed by the farmer's practices in chickpea crop.

\section{Materials and Methods}

The present study was carried out by the Krishi Vigyan Kendra, JAU, Pipalia (Rajkot) in rabi season in the Ten farmers field of Rajkot district during 2015-16 to 2017-18. All
30 front line demonstrations in 12 ha area were conducted in different villages with active participation of farmer.. Before conducting FLDs a list of farmers was prepared from group meeting and specific skill training was imparted to the selected farmers regarding different aspect of cultivation (Venkattakumar et al., 2010). The objective of FLD's was to transfer the improved varietal technology to increase the productivity of chickpea. The difference between demonstration package and existing farmers practice are given in Table 1. All demonstrations were conducted on medium black soils with area of 0.4 ha. The improved chickpea variety GG - 5 is sown in $45 \times 10 \mathrm{~cm}$ spacing was demonstrated on their fields with rate of $65 \mathrm{~kg}$ seed/ha. The inputs like improved variety, Plant protection measures were under taken as per necessary. The necessary steps for selection of site and farmers, layout of demonstration etc. The data output were collected from both demonstrated plot as well as farmers practices and finally the extension gap, technology gap, technology index along with benefit cost ratio were workout (Samui et al., 2000) as given below:

Technology gap $=\mathrm{Pi}($ Potential yield $)-\mathrm{Di}$ (Demonstration yield)

Extension gap $=$ Di $($ Demonstration yield $)-F i$ (Farmers Yield)

Technology index $(\%)=($ Technology gap $/$ Potential yield) $\times 100$

\section{Results and Discussion}

\section{Yield}

The data presented in Table 2 revealed that The GG - 5 variety of chickpea performed better in all three years as compare to farmer practices. The GG - 5 recorded maximum and minimum yield in Rabi season year 2016-17 
and 2015-16 with $2880 \mathrm{~kg} / \mathrm{ha}$ and $2260 \mathrm{~kg} / \mathrm{ha}$, respectively. The average yield of three years was recorded $2590 \mathrm{~kg} / \mathrm{ha}$ as compared to local variety $2193 \mathrm{~kg} / \mathrm{ha}$. The percent increase in yield was ranging from 4.0 to 24.66 with an average of $13.66 \%$ during the three year FLD programmes. Similar yield enhancement in different crops in frontline demonstration has been documented by Poonia and Pithia (2011), Patel et al., (2013) and Raj et al., (2013). It is evident from the results that the yield of improved variety was found better than the local variety under same environment conditions. Farmers were motivated by results of demonstrated agro-technologies applied in the FLDs and it is anticipated that they would adopt these technologies in future. Yield of front line demonstration and potential yield of the crop was compared to estimate the yield gaps which were further categorized into technology index.

\section{Technology gap}

The technology gap is the demonstration yield over potential yield. The technology gap was ranged between $120-740 \mathrm{~kg} / \mathrm{ha}$ with a mean of three years $410 \mathrm{~kg} / \mathrm{ha}$ during period of study. The technology gap may be attributed to the dissimilarity in the soil fertility status and weather conditions (Mukherjee, 2003 and Mitra and Samajdar, 2010).

\section{Extension gap}

The highest extension gap was $450 \mathrm{~kg} / \mathrm{ha}$ recorded in the year 2015-16 and minimum $370 \mathrm{~kg} / \mathrm{ha}$ was observed in both year of 201617 and 2017-18. This emphasized the need to educate the farmers through various means for the adoption of improved agricultural production technologies to reverse this trend of wide extension gap. More and more use of latest production technologies with high yielding variety will subsequently change this alarming trend of galloping extension gap.

The new technologies will eventually lead to the farmers to discontinue the old technology and to adopt new technology. This finding is in corroboration with the findings of Hiremath and Nagaraju (2010).

\section{Yield}

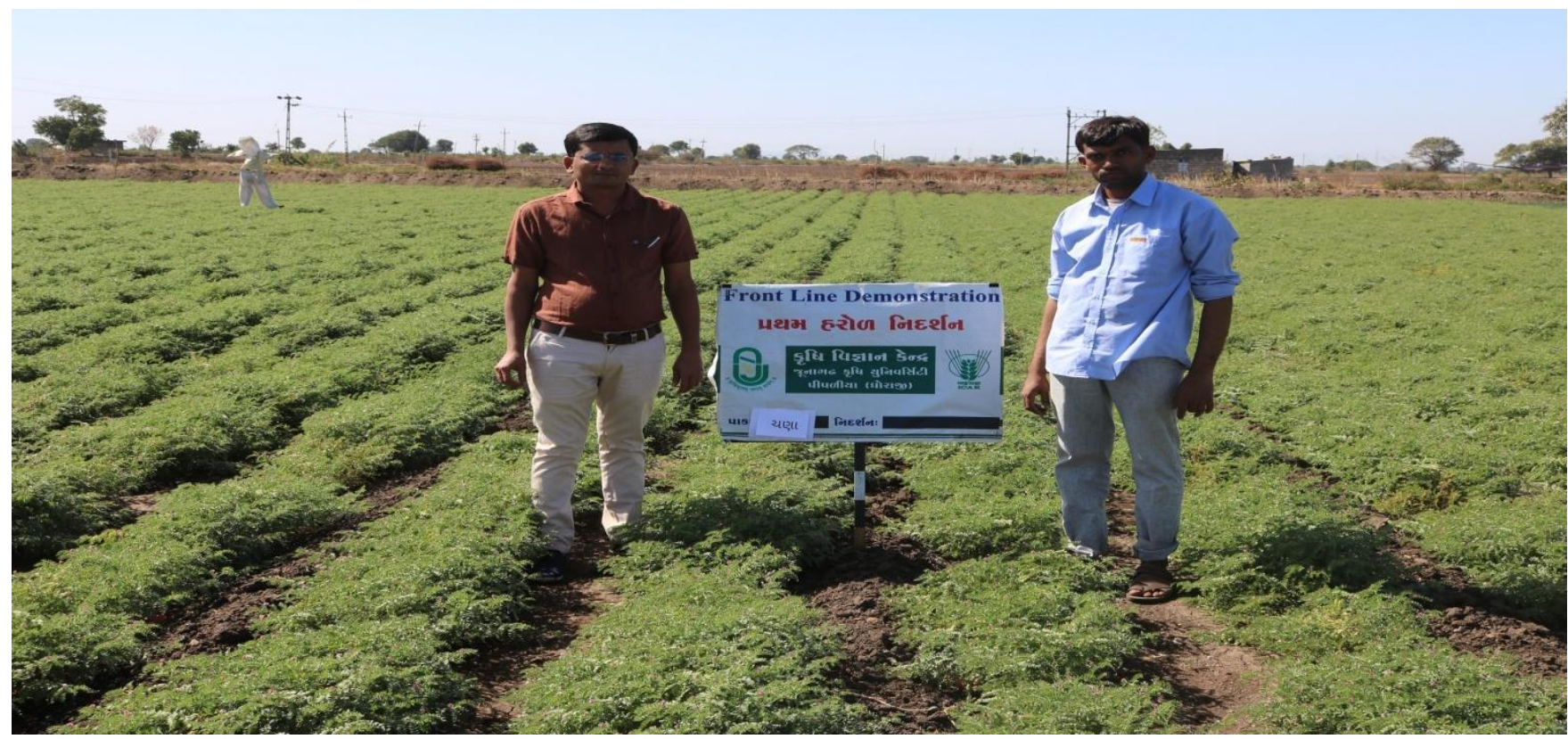


Table.1 Productivity, technology gap, extension gap and technology index of chickpea under FLDs

\begin{tabular}{|c|c|c|c|c|c|c|c|c|c|}
\hline \multirow{2}{*}{$\begin{array}{l}\text { Sr. } \\
\text { No }\end{array}$} & \multirow[t]{2}{*}{ Year } & \multirow{2}{*}{$\begin{array}{c}\text { No. of } \\
\text { Farmers }\end{array}$} & \multirow{2}{*}{$\begin{array}{c}\text { Area } \\
\text { (ha) }\end{array}$} & \multicolumn{2}{|c|}{ Yield (Kg/ha) } & \multirow{2}{*}{$\begin{array}{c}\text { \% Increase } \\
\text { over } \\
\text { control }\end{array}$} & \multirow{2}{*}{$\begin{array}{c}\text { Technology } \\
\text { Gap (Kg/ha) }\end{array}$} & \multirow{2}{*}{$\begin{array}{c}\text { Extension } \\
\text { gap (Kg/ha) }\end{array}$} & \multirow{2}{*}{$\begin{array}{l}\text { Technology } \\
\text { Index }(\%)\end{array}$} \\
\hline & & & & $\begin{array}{c}\text { Demonstrated } \\
\text { practices }\end{array}$ & $\begin{array}{l}\text { Farmer's } \\
\text { practices }\end{array}$ & & & & \\
\hline 1 & $2015-16$ & 10 & 4.0 & 2260 & 1810 & 24.86 & 740 & 450 & 24.66 \\
\hline 2 & 2016-17 & 10 & 4.0 & 2880 & 2510 & 14.43 & 120 & 370 & 4.00 \\
\hline \multirow[t]{2}{*}{3} & 2018-19 & 10 & 4.0 & 2630 & 2260 & 16.30 & 370 & 370 & 12.33 \\
\hline & Average & 10 & 4.0 & 2590 & 2193 & 18.53 & 410 & 396.66 & 13.66 \\
\hline
\end{tabular}

Table.2 Economics of frontline demonstrations

\begin{tabular}{|c|c|c|c|c|c|c|c|c|}
\hline \multirow{2}{*}{ Year } & \multicolumn{2}{|c|}{$\begin{array}{c}\text { Cost of Cultivation } \\
\text { (Rs./ha) }\end{array}$} & \multicolumn{2}{|c|}{ Gross return (Rs./ha) } & \multicolumn{2}{c|}{ Net return (Rs./ha) } & \multicolumn{2}{c|}{ B:C ratio } \\
\cline { 2 - 9 } & DP & FP & DP & FP & DP & FP & DP \\
\hline $\mathbf{2 0 1 5 - 1 6}$ & 54750 & 54200 & 158200 & 126700 & 103450 & 72500 & $1: 2.88$ & $1: 2.33$ \\
\hline $\mathbf{2 0 1 6 - 1 7}$ & 57362 & 56712 & 172500 & 150750 & 115138 & 94038 & $1: 3.01$ \\
\hline $\mathbf{2 0 1 7 - 1 8}$ & 58899 & 56712 & 92093 & 79183 & 33194 & 22475 & $1: 1.50$ \\
\hline Average & 57003 & 55874 & 140931 & 118877 & 83927 & 63004 & $1: 1.39$ \\
\hline
\end{tabular}

$\mathrm{DP}=$ Demonstrated practices, $\mathrm{FP}=$ Farmer practices 


\section{Technology index}

The technology index shows the feasibility of the technology at the farmer's field. The lower the value of technology index more is the feasibility. As such, fluctuation in the technology index was presented in Table 1 that is from 4.00 to 24.66 per cent during period of study. These findings corroborate with the findings of Mokidue et al., (2011) and Tomar (2003).

\section{Economics of frontline demonstrations}

The year wise economics of chickpea cultivation with adoption of improved technology and farmers practices has been presented in Table 2. The results of economic analysis of chickpea production revealed that the average gross expenditure of demonstration practices was $2.03 \%$ higher than farmer's practices But, front line demonstrations average of three year recorded higher gross returns (Rs. 118877/ha) and net return (Rs. 83927/ha). The benefit cost ratio of demonstration practices (1:2.46) also more than the farmer's practice. Sreelakshmi et al., (2012), Joshi et al., (2014) and Sharma et al., (2016) also reported higher net returns and $\mathrm{B}: \mathrm{C}$ ratio in the FLDs on improved technologies compared to the farmer's practices and are at par with results in higher net returns through FLDs on improved technologies.

The findings of the study revealed that wide gap exist in demonstration yield and farmer's practices in chickpea due to technology and extension gap in Rajkot district of Gujarat. The percent increment in yield of chickpea to the extent of $18.53 \%$ in FLDs over the farmers' practices created greater awareness and motivated the other farmers to adopt the improved package of practices of gram. These demonstrations trails also enhance the relationship and confidence between farmers and KVK scientists. The recipient farmers of FLDs also play an important role as source of information and quality seeds for wider dissemination of the improved varieties of chickpea for other nearby farmers. It is concluded that the FLD programme is a successful tool in enhancing the production and productivity of chickpea crop through changing the knowledge, attitude and skill of farmers.

\section{References}

Anonymous, (2009). Directorate of Agriculture, Gujarat State, Gandhinagar.

Hiremath, S. M. and Nagaraju, M. V. (2010). Evaluation of on-farm front line demonstrations on the yield of chilli. Karna. J. Agril. Sci., 23(2):341-342.

Joshi, N. S. Bariya, M. K. and Kunjadia, B. B. (2014). Yield gap analysis through front line demonstrations in wheat crop. International Journal of Scientific Research Publication, 4(9): 1-3.

Meena, K. C. (2011). An impact assessment of frontline demonstrations (flds) on soybean growers. Raj. J. Ext. Edu., 19: 133-138.

Mitra, B. and Samajdar, T. (2010). Field gap analysis of rapeseed-mustard through front line demonstration. Agricultural Extension Review, 22: 16-17.

Mokidue, I. Mohanty, A. K. and Sanjay, K. (2011). Corelating growth, yield and adoption of urdbean technologies, Ind. J. Ext. Edu., 11(2): 20-24.

Mukherjee N. (2003). Participatory, learning and action. Concept, Publishing Company, New Delhi, Pp. 63-65.

Narasimha, Rao, S., Satish, P. and Samuel, G. (2007). Productivity improvement in soybean (Glycine max L. Merrill) through technological interventions. $J$. Oilseeds Res., 24(2): 271-273. 
Patel, M. M., Jhajharia, A. K., Khadda, B. S. and Patil, L. M. (2013). Front-line Demonstration: An effective Communication Approach For dissemination of sustainable cotton production technology. Indian Journal of Extension Education and Rural Development, 21: 60-62.

Poonia, T. C. and Pithia M.S. (2011). Impact of front line demonstrations of chickpea in Gujrat. Legume Research, 34(4): 304- 307.

Raj, A. D., Yadav, V. and Rathod, J. H. (2013). Impact of Front Line Demonstrations (FLD) on the yield of pulses. International Journal of Scientific and Research Publications. Volume 3, Issue 9, September 2013.

Samui, S. K., Maitra, S., Roy, D. K., Mandal, A.K. and Saha, D. (2000). Evaluation of front line demonstration on groundnut (Arachis hypogeal L.) Journal of Indian Society of Coastal Agricultural Research, 18(2): 180-183.
Sharma, Vivek, Kumar, V. Sharma, S. C. and Singh, S. (2016). Productivity enhancement and popularization of improved production technologies in wheat through frontline demonstrations. Journal of Applied Natural Science, 8(1): 423-428.

Sreelakshmi, C. H., Sameer Kumar, C. V. and Shivani, D. (2012). Productivity enhancement of pigeonpea (Cajanus cajan L.) through improved production technology. Madras Agricultural Journal, 99 (4-6): 248-250.

Tomar, L. S., Sharma, B. P. and Joshi, A. (2003). Impact of frontline demonstration of soybean in transfer of improved technology. J. Ext. Edu., 22(1): 139.

Venkattakumar, R., Ramana Rao, S. V. Padmaiah, M. and Madhuri, P. (2010). Production constraints and information needs of oilseeds growers in Andhra Pradesh. Agricultural Extension Review, 22(2): 25-28.

\section{How to cite this article:}

Undhad, S.V., V.S. Prajapati, P.S. Sharma and Jadav, N.B. 2019. Impact of Frontline Demonstration on the Yield and Economics of Chickpea (Cicer arietinum L.) production in Rajkot District of Gujarat. Int.J.Curr.Microbiol.App.Sci. 8(08): 95-100. doi: https://doi.org/10.20546/ijcmas.2019.808.011 